submitted to Agricultural Extension and Rural Development Department, University of Ibadan, Ibadan. 226 pp.

http://dx.doi.org/10.4314/jae.v18i2.2

\title{
Livelihood Diversification Sources of Female Household Heads in Rural Communities of Osun State
}

\author{
Adesoji, S. A., Olanrewaju K. O. and Kolawole O. F. \\ Department of Agricultural Extension and Rural Development, Faculty of Agriculture, \\ Obafemi Awolowo University, Ile Ife. \\ Telephone: +2348035605062 E-mail: dapadesoji@yahoo.co.uk
}

\begin{abstract}
The study investigated the livelihood of female household heads (FHH) in rural communities of Osun State. Specifically, it described the personal and socioeconomic characteristics of female household heads, identified their livelihood sources and investigated the problems faced their sources of external assistance/support. Multi-stage sampling procedure was employed to select 120 respondents to whom structured questionnaires were administered to elicit requisite information. Frequency counts, percentage, means and standard deviation were used for data analysis. The results showed that the female household heads were mainly widows (55\%) and the mean age and household size were 50.46 \pm 13.07 and 5.46 \pm 2.09 , respectively. The major livelihood sources were petty trading (97.5\%), crop processing (57.5\%), farming (48.3\%) and reselling of farm produce (22.2\%). Financial difficulty was a paramount problem identified, followed by lack of contact with extension agents (71.7\%) and gender discrimination in obtaining land on lease for farming (39.2). Majority (65.8\%) of FHH did not have external sources of financial assistance while $21.7 \%$ were supported by their children. The study concluded that livelihoods of FHH were diversified mainly within agriculture and trading enterprises.
\end{abstract}

Key words: Livelihood diversification, Female household heads, Rural communities.

\section{Introduction}

Livelihood encompass the activities, assets, and access that jointly determine the living gained by an individual or household (Ellis, 1999). It is both the economic activities (agricultural and non-agricultural) and non-economic activities that people know own and undertake to earn income today and into the future (Oyesola and Ademola, 2012). Diversification on its own refers to attempts by individual and households to find new ways to raise incomes and reduce vulnerability to different livelihood shocks (Diliruba and Roy, 2012). Thus, rural livelihood diversification conceptually refers to the process by which households construct a diverse portfolio of activities and social support capabilities for survival and in order to improve their standard of living (Ellis, 1999). It also entails all attempts by individuals and households to find new ways to raise incomes and reduce environmental risk (both on and off-farm activities), which differ sharply by the degree of freedom of choice and the reversibility of the outcome (Oluwatayo, 2009). Of increased importance in rural household livelihood portfolio is the remittances from non-agricultural 
activities as agriculture alone no longer provides sufficient livelihood opportunities or survival means for the rural dwellers (Oluwatayo, 2009; Ellis, 1999). In essence, rural households' age long total reliance on agriculture for income and food sources is changing ground.

Given the poverty situations in rural communities and uncertainties associated with the largely nature-dependent economy of traditional agricultural practice, the need for rural household livelihood diversification is centred on the need for assurance of household food security, generation of additional income, control of available additional income, reduction of poverty and vulnerability among others (Ajani and Igbokwe, 2013). It is also, opined that increased diversity promotes greater flexibility because it allows more possibilities for substitution between opportunities that are in decline and those that are expanding. Ellis (1999) also submitted that considerations of risk spreading, consumption smoothing, labour allocation smoothing, credit market failures, and coping with shocks can contribute to the adoption, and adaptation over time, of diverse rural livelihoods. To this end, it is noted that households in rural Nigeria engage in multiple jobs to diversify their income source as they hardly specialise in the production of a single crop but grow diverse crops, involved in varied crop processing activities and also engage in other nonfarm income generating activities to augment their meagre income (Oluwatayo, 2009).

Bryceson (2014) also argued that the income diversification efforts of most rural dwellers over the past decade have been directed at meeting daily needs amidst declining returns to commercial agriculture. This was the basis of individuals and households experimenting with new forms of livelihood, expanding their non-agricultural income sources, while retaining their base in subsistence and small scale agricultural activities. The strategies employed in this wise is shaped by the rural households' asset stock, access to productive resources, structures and processes, opportunities and vulnerability contexts (Karttunen, 2012; Ellis, 1999).

As women typically confront narrower range of labour markets than men, and lower wage rates, female headed households are distinguished with their characteristic poor asset base, lower income and poor or lack of control over productive resources which makes them poorer than the male headed households. Consequently, livelihood diversification is beyond a mere option for female household heads but a survival strategy (Zegraw, 2007; Oluwatayo, 1999; Ellis 1999; Yusuf and Adisa, 2011). Worku (2007) also asserted that female-headed households are economically inferior in relation to male headed households and are a disadvantaged group due to their largely poor education, smaller landholding sizes as well as labour force and other assets constraint among others. In fact, Buvinic and Gupta (1997) observed that FHHs are over-represented among the poor. Thus, livelihood diversification in the case of female headed households' in rural communities is a strategic measure of managing or escaping from poverty.

Ellis (1999) noted that diversification improve the independent income-generating capabilities of women and by extension the household, female household heads are more in need of diversifying their income source in order to be able to bear the brunt of their household needs. However, the sources harnessed in their livelihood diversification efforts are shaped by the different agro-climatic conditions, natural resource base, rural 
infrastructures as well as socio-cultural contexts. Hence, it is pertinent to investigate the activities undertaken by the women performing dual purpose of household bread winner and care giver or home maker in a bid to earn a living to sustain the households.

\section{Objectives of the Study}

The specific objectives of the study were to:

i. describe the personal and socio-economic characteristics of female household heads $(\mathrm{FHH})$;

ii. identify the livelihood sources of the $\mathrm{FHH}$; and

iii. investigate the problems faced by $\mathrm{FHH}$ and their sources of external assistance

\section{Methodology}

\section{Study area}

The study area was Osun State, a tropical state in South west; Nigeria lying within coordinates $7^{0} 30^{\prime} \mathrm{N}$ and $4^{0} 30^{\prime} \mathrm{E}$. The state comprised of 30 Local Government Areas (LGAs) distributed over three main agro-ecological zones. According to NPC (2006), Osun State has a population of 3,423,535 and the people are predominantly Yoruba.The people of the state are mostly farmers, traders, and artisans. The farmers produce food crops such as yam, maize, cassava, beans and cocoyam and the main cash crops grown include cocoa, kola and palm produce. The artisans make hand-woven textiles, tie and dye clothes, leather work, calabash carving and mat-weaving among others.

\section{Sampling procedure and sample size}

Multi-stage sampling procedure was used for data collection. At the first stage, one sixth (5) of the states' LGAs, namely Ayedaade, Ede South, Orolu, Ife Central and Atakumosa West were chosen randomly. At the second stage, two most rural communities were purposively selected from each LGA making 10 rural communities. Finally, 12 female household heads were identified through snow-ball technique to give a total of 120 respondents interviewed for this study. Data were collected using validated interview schedule on socio-economic characteristics of female household heads, the livelihood sources, livelihood problems faced and the sources of external assistance. Data obtained were analysed with descriptive statistics such as frequency, percentage, mean, standard deviation were used, while Chi-square and correlation were used to draw inferences.

\section{Results and Discussion}

\section{Socio-economic characteristics of respondents}

Age

The $\mathrm{FHH}$ between the middle age range of $36-55$ years and $55-65$ years constituted $44.2 \%$ and $22.5 \%$, respectively. Lower proportions, $18.3 \%$ and $15 \%$ were aged below 36 years and above 66 years. The mean age was found to be 50.46 years with standard deviation of 13.08. This indicates that the female household heads were in their productive age and thus capable of delving into many activities to make a living. This underscores the findings of Ajani and Igbokwe (2013) which noted rural women were in their productive years and hence greater involvement in both farm and non-farm activities. 


\section{Religion}

Many $(60.8 \%)$ of the respondents practiced Christianity, $38.3 \%$ indicated Islam as their religion while only 0.8 percent were traditional worshippers. This indicated that the respondents were mainly Christians and Muslims and thus could be identified through faith based organizations in case of livelihood intervention programmes. The proportion is however in contrast with the findings of Yusuf and Adisa (2011) which indicated majority of rural female household heads in Osun State to be Muslims.

\section{Marital status}

More than half $(55.0 \%)$ and less than a fifth $(16.7 \%)$ of the respondents were widowed and divorced, respectively. The others were separated from their husbands due to occupation $(6.7 \%)$, misunderstanding $(3.3 \%)$, and accommodation problems $(0.8 \%)$. This implied that widowhood was the main reason for the emergence of female house heads in the study area. It is also noted that varied location of livelihood sources was the main cause of separation leading to emergence of $\mathrm{FHH}$. This backed the findings of Yusuf and Adisa (2011) which established widowhood mainly accounted for the emergence of female headed households in Osun State.

\section{Household size}

Majority (86.7\%) of the respondents had family size less than or equal to 5 percent, also 11.7 percent had between $6-8$, while only $1.7 \%$ had household size of 9 percent and above. The mean household size was 5.06 with standard deviation of 2. This also corroborates the result of Ajani and Igbokwe (2013) who found that majority of rural women had a household size of 1-5 persons. The lower figure of mean household size of the respondents compared to the average of 6 noted in many studies points out that female headed households are relatively smaller in size than typical traditional male headed rural households. This could account for the labour shortages which are known to limit agriculture in female households thereby promoting non-farm diversification among them.

\section{Number of years of formal education}

High proportion of the respondents $(62.5 \%)$ spent less than or equal to 4 years in formal education, a quarter (25.8\%) spent between 5-8 years, 7.5percent spent 9-12 years, while the least percentage 4.2 percent spent 13 years or more in the pursuit of formal education. This showed that many of the respondents had no or absolutely low exposure to formal education with no qualification. Hence, it is pointed out that FHHs are largely uneducated. This finding supports the assertion that female household heads are poorly educated (Saito et al., 1994; Worku 2007; Babulo et al. 2008; Yusuf and Adisa, 2011).

\section{Ownership of apartment}

Nearly all the respondents do not own the apartment they lived in, as about half $(51.7 \%)$ of them lived in their spouses' apartment or family house while a quarter and a fifth lived in rented and parents' apartments, respectively. Just 3\% owned the apartment they lived in. This showed that only a considerably small proportion of the respondents had an apartment of their own while most of them rely on spouses' residents or family house and their parents' for shelter. This implied that most of the FHHs are dependent on others for 
fulfilling their basic need of shelter for themselves and their household members. It also reflects the poor asset base of female headed household pointed out in many studies.

\section{Average annual income}

Majority (80\%) of the respondents had their average annual income to be less than or equal to $\$ 50,000,13.3$ and $4.2 \%$ earned $\$ 50,001-\$ 100,000$ and $\$ 100,001-\$ 200,000$, respectively, while only $1.7 \%$ and $0.8 \%$ earned $\$ 200,001-\$ 300,000$. and more than $\# 300,000$, respectively, annually. This showed that the average annual income of most of the respondents was below $\$ 50,000$ which translates to a mean daily income of about \$137 (approximately $\$ 0.54$ ). The smallness of the income compounded with the huge responsibility of catering for the needs of household members could be noted as responsible for the abject poverty characterizing female headed households. In line with this is the finding of Apata et. al. (2010) that female headed households' and distance to the market increases the probability of persistence in chronic poverty.

\section{Land acquisition for agriculture}

High proportion $(45 \%)$ of the respondents made use of leased land for their agricultural production and $25 \%$ employed inherited lands, while significantly low proportions, $5 \%$ and $3 \%$ acquired through purchase and those given as gifts, respectively. Contrary to the findings of Yusuf and Adisa (2011) that majority of FHH cultivated inherited land, most of those who had access to land for agricultural production acquired such land through lease. This necessitates payment of rental charges to the land owner form the meager income noted by this study. This might have negative implication on their poverty situation and promote off farm livelihood diversification.

\section{Farm size}

Close proportions, $39.2 \%$ and $32.5 \%$ of the respondents cultivated farm sizes below $1 \mathrm{Ha}$ and $1-2 \mathrm{Ha}$, respectively, while only $4.1 \%$ had farm sizes above $2 \mathrm{Ha}$. Also, the mean farm size was found to be 1.2 with standard deviation of 0.77 which is close to the result of Yusuf and Adisa (2011) who found the mean of female household heads' farm sizes as 1.1. This indicates that majority of the respondents operated farms below $2 \mathrm{Ha}$ in size. It is reflected from this result that female household heads had small farm holdings. This implies that majority of the women did not have big farms and even the little they had, they could not utilize them effectively because of lack of funds. 
Table 1: Distribution of respondents by personal and socio-economic characteristics

\begin{tabular}{|c|c|c|c|}
\hline Characteristics & Percentage & Mean & SD \\
\hline \multicolumn{4}{|l|}{ Age } \\
\hline Below 35 & 18.3 & & \\
\hline $35-55$ & 44.2 & 50.46 & 13.07 \\
\hline $56-65$ & 22.5 & & \\
\hline 66 and above & 15.0 & & \\
\hline \multicolumn{4}{|l|}{ Religion } \\
\hline Christianity & 60.8 & & \\
\hline Islam & 38.3 & & \\
\hline Traditional & 0.8 & & \\
\hline \multicolumn{4}{|l|}{ Marital status } \\
\hline Separated & 24.2 & & \\
\hline Divorced & 3.3 & & \\
\hline Widowed & 55.0 & & \\
\hline Not applicable & 17.5 & & \\
\hline \multicolumn{4}{|l|}{ Household size } \\
\hline 5 and below & 86.7 & & \\
\hline $6-8$ & 11.7 & 5.46 & 2.09 \\
\hline 9 and above & 1.7 & & \\
\hline \multicolumn{4}{|l|}{ Average annual income } \\
\hline Below or up to $\$ 50,000.00$ & 80.0 & & \\
\hline$\$ 50,001.00-\$ 100,000.00$ & 13.3 & & \\
\hline$\# 100,001.00-\# 200,000.00$ & 4.2 & & \\
\hline$\# 200,001.00-\approx 300,000.00$ & 1.7 & & \\
\hline$\# 300,001$ and more & 0.8 & & \\
\hline Years of formal education & & 3.12 & 4.47 \\
\hline \multicolumn{4}{|l|}{ Ownership of apartment } \\
\hline Parents & 20.0 & & \\
\hline Rented & 25 & & \\
\hline Personal & 3.3 & & \\
\hline Spouses & 51.7 & & \\
\hline \multicolumn{4}{|c|}{ Land acquisition for agric. production } \\
\hline Lease & 45 & & \\
\hline Inheritance & 25 & & \\
\hline Purchase & 5 & & \\
\hline \multirow{2}{*}{\multicolumn{4}{|c|}{ Farm size $(\mathrm{Ha})$}} \\
\hline & & & \\
\hline$<1$ & 32.5 & & \\
\hline $1-2$ & 39.2 & 1.2 & 0.77 \\
\hline$>2$ & 4.1 & & \\
\hline
\end{tabular}

Source: Field survey, 2013.

\section{Livelihood sources of female household heads}

Evidence in Figure 1 revealed the various activities from which the respondents derived their livelihood. Majority of the respondents $(79.2 \%)$ indicated they were involved in petty trading and $10.8 \%$ noted they were artisans. Regarding agricultural livelihood sources, high proportions, $57.5 \%$ and $48.3 \%$ were involved in crop processing and crop farming, respectively, just as about a quarter (24.2\%) were engaged in merchandizing of farm produce and only a respondent was selling farm implements. Also, $6.7 \%$ and $4.2 \%$ of the respondents were manual labourers and food sellers, respectively, while $3.3 \%$ and $0.8 \%$ were engaged in the operation of pepper grinding machines and civil servant, respectively. 
These results revealed that majority of the respondents were involved in one form of petty trading or the other alongside agricultural related activities. The importance of agriculture is also underscored by the high proportions of respondents involved in different levels of agricultural production up to marketing. This result is similar to that of Letha and Vijayaragavan (2010) which noted as much as $45 \%$ of rural women livelihood source is in agriculture while only $5 \%$ were engaged in industries. More so, only one out of the 120 respondents sampled was engaged in salaried job (civil service) which means the other 119 respondents were engaged in agriculture, personal businesses, artisan works and menial job and this is in consonance with the assertion that female headed households diversify into casual and informal activities (Worku, 2007). The respondents' exploration of varied livelihood sources also corroborates the findings of Ayanwuyi and Akintonde (2011) that women in Ila Local Government of Osun State engaged in varieties of livelihood activities in order to ensure household food security.

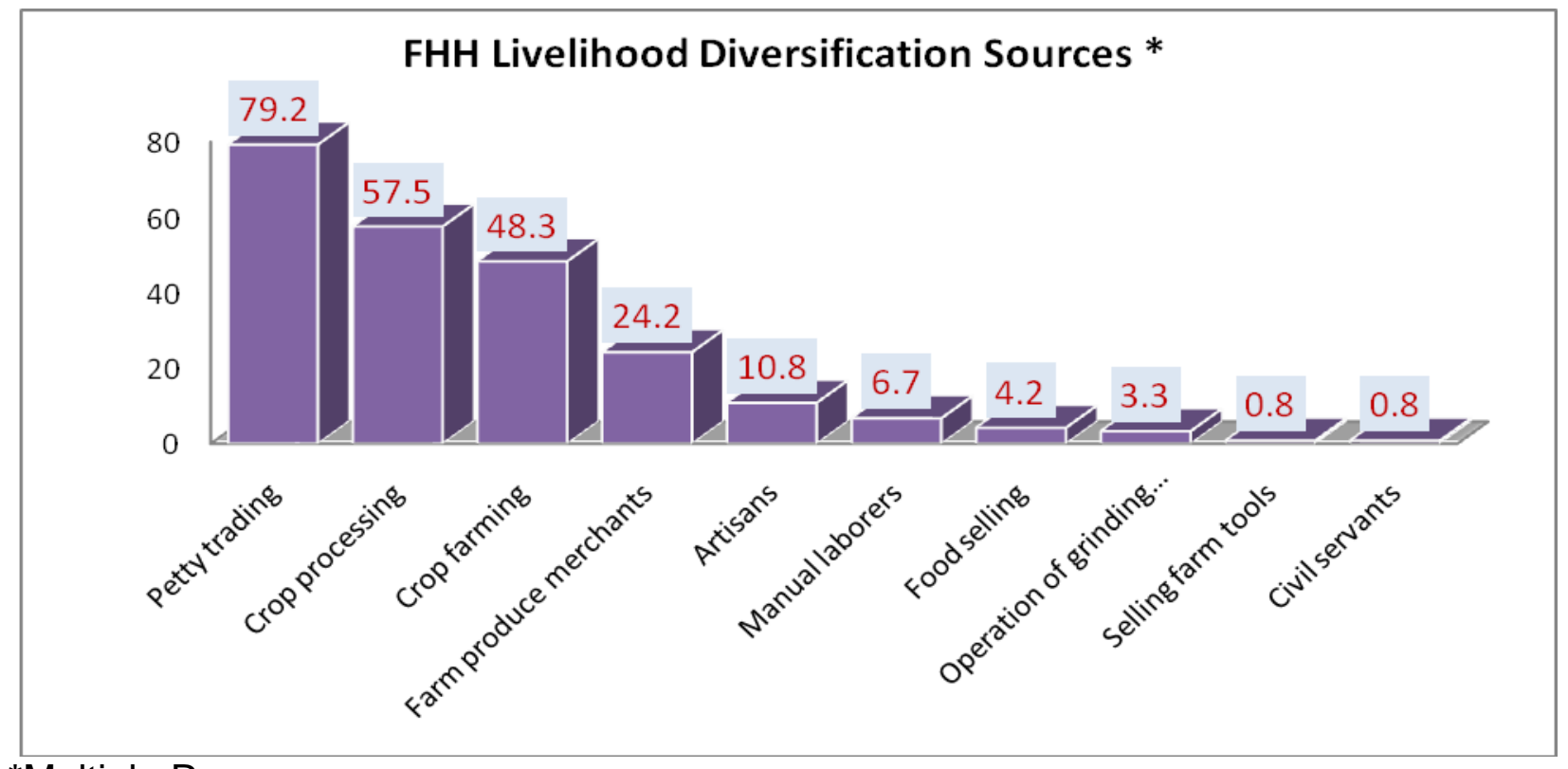

*Multiple Responses

Figure 1: Distribution of respondents by livelihood sources.

\section{Difficulties Encountered By Female Household Heads}

Nearly all the respondents indicated they were faced with financial difficulties due to incapacity of income to adequately cater for their household needs. Most of them (96.2\%) indicated the problem of lack of collaterals as impeding them from obtaining bank loans. It could be noted from this result that the female household heads livelihood was beset with financial problems which could not be ameliorated through credit procurement through bank loans due to lack of viable collaterals. Thus, most of the female household heads were financially handicapped to invest tangible capital capable of yielding substantially in their livelihood production activities. Also, majority (73.3\%) indicated high cost of quality farming equipment and improved inputs as a challenge inhibiting their agricultural production.

In the same vein, most of the respondents (89.2\%) indicated that they were faced with the problem of gender discrimination in land acquisition on lease noting that most land 
owners prefer to contract their lands to men. Hence, only unsolicited land may be available to the $\mathrm{FHH}$ and these may not contracted to them timely especially at the onset of planting season which makes them to lag behind in agricultural production. It is thus implied that female household heads are less opportune to access land for agricultural production even when they are willing to pay or fulfill the necessary terms and conditions. This backed the findings of Yusuf and Adisa (2011) which established that there was a gap in accessibility to productive resources between male and female heads of households in Osun State.

More so, majority of the respondents $(76.2 \%)$ did not have access to extension service which means they are cut out from agricultural, technical and advisory services necessary for updating themselves on improved farming practices and technologies. This implies that most of the female household heads do not have access to expert advices as well as recommendations and would not be conversant with new methods of farming and programmes which could enhance their agricultural production and consequent livelihood upliftment. In summation, female household heads are constrained in their access to productive resources due to their poor asset base, poor economic conditions as well as societal relegation or gender discrimination.

\section{FHH sources of financial assistance}

The result in Figure 2 reveals that $65.8 \%$ of the female household heads had no external source of assistance apart from their own little earnings, $21.7 \%$ percent of them had their children as their source of assistance while $6.7 \%$ were supported by their parents. Very low proportions, $2.5 \%$ and $0.8 \%$ were supported by relatives and friends, respectively.It is indicated from these results that many of the female household heads did not have external source of assistance which implies that they bear the household economic burden alone.However, children constituted a major source of assistance to the few female household heads who were supported followed by their parents, while insignificant proportions were assisted by relatives and friends. This underscores the findings of Azmi (nd); Letha and Vijayaragavan, (2010) which noted the contribution of income from foreign sources to the livelihood of rural women.

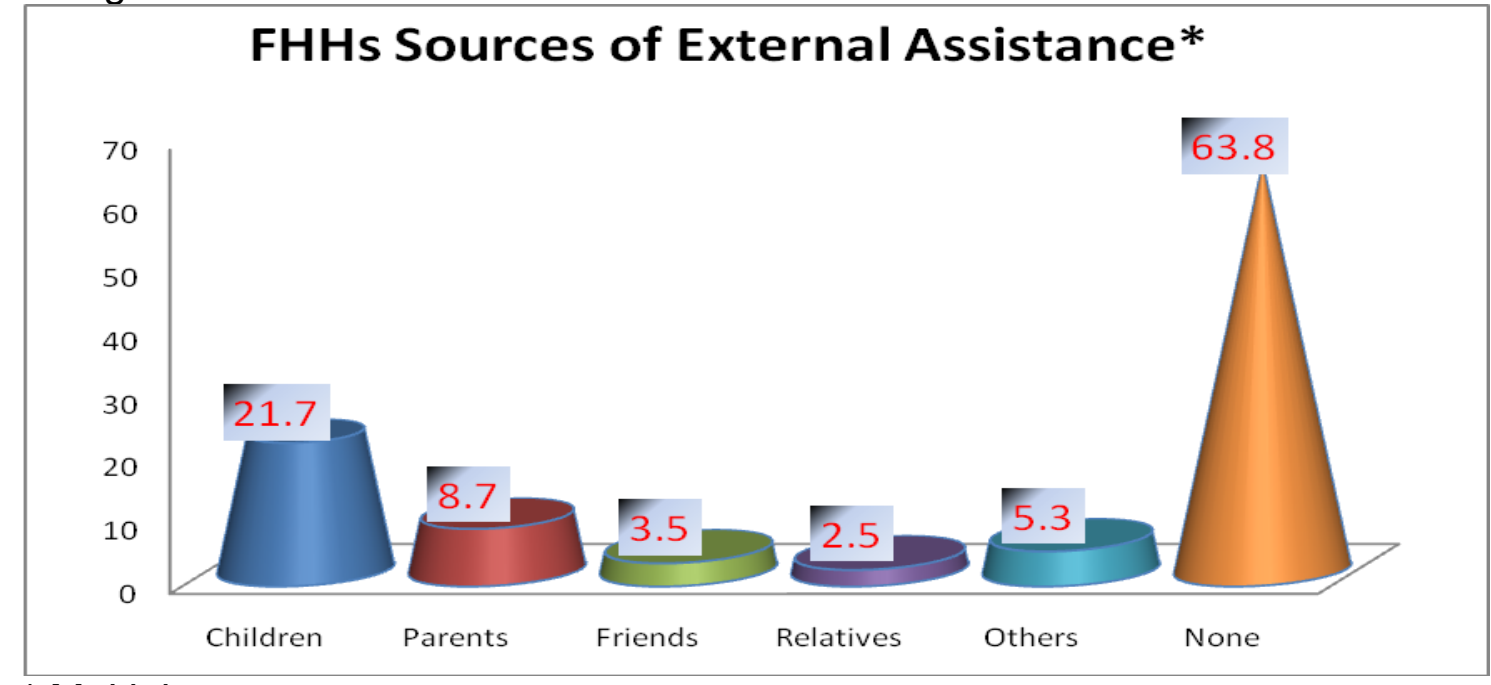

${ }^{\star}$ Multiple responses

Figure 2: Distribution of respondents by sources of external assistance 
Relationship between female household heads' personal and socio-economic characteristics and their livelihood diversification The result of correlation analysis (Table 2) reveal that farm size $(r=0.279)$ and annual income $(r=0.285)$ had significant relationship with female household heads livelihood diversification. This indicates that FHHs with large farm holdings and corresponding higher income than their counterparts would have sufficient resource base needed to explore varied livelihood sources. As such, FHHs economic strength underscores their livelihood diversification in a view to enhancing their household sustainability.

Table 2: Correlation between female household heads' personal and socioeconomic characteristics and their livelihood diversification

\section{Characteristics Correlation coefficient ( $r$ )}

\begin{tabular}{ll}
\hline Age & -0.69 \\
Household size & 0.17 \\
Years of formal education & 0.067 \\
Farm size & $0.279^{\star *}$ \\
Income & $0.285^{\star *}$
\end{tabular}

** Significant at $p \leq 0.01$

\section{Conclusion}

The following conclusions were drawn from the findings of this study:

1. FHHs are middle aged and poorly educated with relatively smaller household sizes than typical traditional rural households.

2. Widowhood was the major reason for the emergence of FHHs and most of them depend on spouses' residents or family house and their parents' for shelter just as many of them utilize leased land for their agricultural production.

3. The FHHs explore varied livelihood sources with agriculture and trading constituting the main diversification sources.

4. FHHS are constrained in their access to productive resources due to their poor asset base and economic conditions as well as societal relegation stemming from gender discrimination.

5. Only few of the FHHs had external source of assistance and their children were the major source of such assistance.

6. Economic strength of FHHs is associated with the degree at which their livelihood is diversified.

\section{Recommendations}

1. Urgent intervention is needed to regress the trend of gender discrimination in access to productive resources as a panacea for sustainable development.

2. Social support services should be initiated to help the disadvantaged female headed households out of poverty. 


\section{References}

Ajani E. N. and Igbokwe E. M. (2013). Analysis of occupational diversification among rural women in Anambra State, Nigeria. International journal of Agricultural Sciences 3(2): $\quad$ 419-427.

Apata T. G., Apata, O. M., Igbalajobi1 O. A. and Awoniyi. S. M. O. (2010). Determinants of rural poverty in Nigeria: Evidence from small holder farmers in South-western, Nigeria. Journal of Science and Technology Education Research Vol. 1(4): 85 91.

Ayanwuyi E. and Akintonde, J. O. (2011). Income Generating Activities among Rural Women inEnsuring Household Food Security in lla Local Government, Osun State. World Journal of Young Researchers, 1(5):66-70.

Azmi F. (nd) Challenges to rural women Livelihood Strateies in dry Peasant colonization Scheme in rural SriLanka. Department of Geography, NTNU Dragvoll, N 7491, Trondheim, Norway.

Babulo, B., Muys, B., Nega, F., Tollens, E., Nyssen, J., Deckers, J. and Mathijs, E. (2008). Household livelihood strategies and forest dependence in the highlands of Tigray, Northern Ethiopia. Agricultural Systems 98: 147-155

Bryceson D. F. (2014) Multiplex livelihoods in rural Africa: recasting the terms and conditions of gainful employment

Buvinic, M. and G.R. Gupta. 1997. Female-Headed Households and Female-Maintained

Dilruba K. and B.C. Roy (2012). Rural Livelihood Diversification in West Bengal: Determinants and Constraints. Agricultural Economics Research Review 25(1): $115-124$

Ellis F. (1999) Rural Livelihood Diversity in Developing Countries: Evidence and Policy Implications. Natural Resource Perspectives No. 40. Overseas Development Institute.

Karttunen A. K. (2012) Promoting Rural Women's Access to Income Generating Opportunities and Social Protection. United Nations Commission on the Status of Women Fifty-sixth session held 27 February - 9 March 2012, New York Interactive Expert Panel.

Letha D. G and K. Vijayaragavan (2010) Livelihood Options of Rural Women in Kerala: A Critical Analysis. Indian Research Journal of Extension Education 10 (2): 45-47. 
National Population Commission (2006) National Population and Housing Survey. National Population Commission, Abuja, Nigeria. Retrieved from http://www.poulation.gov.ng/pop.figure.pdf accessed on 25th March, 2013)

Oluwatayo I. B. (2009). Poverty and Income Diversification among Households in Rural Nigeria: A Gender Analysis of Livelihood Patterns. Conference Paper №41 of the 2nd Instituto de EstudosSociais e Económicos (IESE) Conference on 'Dynamics of Poverty and Patterns of Economic Accumulation in Mozambique' at Maputo, Mozambique 22-23 April, 2009.

Oyesola O. B. and Ademola A. O. (2011) Livelihood in University of Ibadan Social Laboratory in Ileogbo Community of Osun State, Nigeria, Journal of Human Ecolology 34(2): 91-100

Saito, K., Spurling, D. and Mekonnen, H. (1994). Raising the productivity of women farmers in Sub-Saharan Africa. World Bank Discussion Papers. Africa technical department series No 230, Washington DC

Worku S. Z. (2007). Livelihood strategies of rural women with emphasis on income diversification and demographic adjustment: The case of Wolonkomi, Oromia region. Working papers on population and land use change in central Ethiopia, nr. 9. Series A, No.17.

Yusuf, O.J. and Adisa B. O. (2011) Gender analysis of accessibility to productive resources by heads of rural households in Osun state, Nigeria. Journal of agriculture and development 7:1-12. 